\title{
Kesediaan Mendapat Vaksinasi Human Papilloma Virus pada Remaja Putri Di Yogyakarta
}

Kurniawati Arifah, Wahyu Damayanti, Mei Neni Sitaresmi

Departemen Ilmu Kesehatan Anak Fakultas Kedokteran Universitas Gadjah Mada, Yogyakarta

Latar belakang. Kanker serviks merupakan keganasan terbanyak keempat pada wanita di dunia. Jumlah kasus baru setiap tahun di Indonesia sebanyak 20.928 dengan kematian 9498. Infeksi Human Papilloma Virus (HPV) risiko tinggi adalah penyebab utama kanker serviks. World Health Organization (WHO) dan Ikatan Dokter Anak Indonesia (IDAI) merekomendasikan vaksinasi HPV untuk wanita 9-14 tahun. Vaksin HPV mulai diberikan melalui bulan imunisasi anak sekolah (BIAS).

Tujuan. Mengetahui kesediaan vaksinasi HPV dan hal-hal yang dipertimbangkan dalam menerima vaksinasi pada remaja putri di Yogyakarta.

Metode. Penelitian cross-sectional dengan kuesioner anonim pada 319 remaja putri yang dipilih secara cluster random sampling pada September-Oktober 2016. Kriteria inklusi adalah pelajar putri sekolah menengah pertama (SMP) di kota Yogyakarta, bersedia mengikuti penelitian, mendapat persetujuan dari pihak sekolah dan orang tua. Lima dieksklusi karena data tidak lengkap.

Hasil. Kesediaan mendapat vaksinasi sebesar 9,9\%. Kehalalan dan keamanan vaksin adalah hal yang dipertimbangkan dalam pengambilan keputusan vaksinasi.

Kesimpulan. Kesediaan mendapat vaksinasi HPV pada remaja putri masih rendah. Sari Pediatri 2017;18(6):430-5

Kata kunci: HPV, kanker serviks, vaksinasi, remaja

\section{Human Papilloma Virus Acceptability among Female Adolescent in Yogyakarta}

Kurniawati Arifah, Wahyu Damayanti, Mei Neni Sitaresmi

Background. Cervical cancer ranks the fourth most frequent cancer in women worldwide. Each year 20,928 women are diagnosed with cervical cancer, and 9498 die of the disease in Indonesia. Persistent infection with high-risk human papilloma virus (HPV) is a necessary step in the pathogenesis of cervical cancer. HPV vaccines are most effective if provided prior to the onset of sexual activity, as recommended by World Health Organization (WHO) and Ikatan Dokter Anak Indonesia (IDAI) young adolescent aged 9-14 years. HPV vaccination will be provided through Bulan imunisasi anak sekolah (BIAS) program.

Objective. To define vaccine acceptability among female adolescent.

Methods. During September-October 2016, a cross-sectional survey of 319 junior high school students using anonymously completed questionnaires was done. Inclusion criteria were female junior high school student in Yogyakarta who willing to participate in the study, school and parental consent. Five incomplete data were excluded.

Results. HPV vaccine acceptability was $9.9 \%$. Adolescent mentioned concern about vaccine halal and safety as possible barrier towards HPV vaccine implementation.

Conclusions: HPV vaccine acceptability among female adolescent was low.Sari Pediatri 2017;18(6):430-5

Kata kunci: HPV, cervical cancer, adolescent, vaccination

Alamat korespondensi: Dr. Kurniawati Arifah, Dr. Wahyu Damayanti, SpA(K). Departemen Ilmu Kesehatan Anak Fakultas Kedokteran Universitas Gadjah Mada, Yogyakarta. Email: ipeychan@gmail.com 
$\mathrm{K}$ anker serviks merupakan keganasan terbanyak keempat di dunia yang menyerang wanita dengan perkiraan kasus baru 500.000 tiap tahun. Jumlah kasus kanker serviks di Indonesia 20.928 per tahun dengan kematian 9498 per tahun. ${ }^{1,2}$ Di Yogyakarta, kanker serviks menduduki peringkat kedua keganasan pada wanita. ${ }^{3}$ Infeksi Human Papilloma Virus (HPV) risiko tinggi merupakan penyebab utama terjadinya kanker serviks. ${ }^{4}$ Pemberian vaksinasi HPV rekomendasi WHO untuk wanita usia 9 sampai 14 tahun karena vaksin akan efektif pada wanita yang belum pernah terinfeksi. Usia tersebut merupakan batas usia sebelum mulai melakukan aktivitas seksual. ${ }^{5}$

Penelitian menunjukkan pemberian vaksin HPV dapat memberikan proteksi 89\%. ${ }^{1}$ Vaksin HPV efektif mencegah kanker serviks dengan cakupan vaksinasi yang bervariasi. Pada umumnya belum optimal, baik untuk inisiasi vaksinasi maupun kelengkapan dosisnya. ${ }^{6}$ Vaksin HPV sudah tersedia di Indonesia dan merupakan salah satu imunisasi pilihan yang dianjurkan oleh Ikatan Dokter Anak Indonesia. ${ }^{7}$ Di Indonesia, vaksinasi HPV masih dalam proses inisiasi sebagai program nasional, diberikan kepada siswi kelas 5 (dosis pertama) dan 6 (dosis kedua) SD/MI melalui program Bulan Imunisasi Anak Sekolah (BIAS). ${ }^{8}$

Vaksinasi HPV pada remaja merupakan suatu intervensi baru, untuk meningkatkan penerimaan vaksin ini, remaja harus memiliki pengetahuan yang cukup tentang pentingnya vaksinasi, manfaat, dan risikonya. ${ }^{9}$ Berbeda dengan vaksinasi anak, vaksinasi pada remaja merupakan kondisi khusus karena memerlukan persetujuan dari remaja tersebut (assent) selain persetujuan dari orang tua (consent). Penelitian ini bertujuan untuk mengetahui kesediaan vaksinasi HPV dan hal-hal yang dipertimbangkan dalam pengambilan keputusan vaksinasi HPV pada remaja di Yogyakarta.

\section{Metode}

Penelitian dengan desain cross-sectional dilakukan pada remaja SMP di kota Yogyakarta pada bulan SeptemberOktober 2016. Kriteria inklusi adalah pelajar putri SMP di kota Yogyakarta, bersedia mengikuti penelitian, mendapat persetujuan dari pihak sekolah dan orang tua. Kriteria eksklusi adalah data kuesioner yang tidak lengkap. Pemilihan subjek penelitian dilakukan dengan cluster random sampling.

Pengambilan data dilakukan menggunakan kuesioner yang diisi secara anonim. Kuesioner awal berisi tata cara penelitian, persetujuan anak dan orang tua, serta data demografi dibagikan kepada 375 pelajar putri dari SMP 2, 5, dan 8 Yogyakarta. Penelitian ini sudah mendapat persetujuan dari Komisi Etik Penelitian Kedokteran FK Universitas Gadjah Mada dan Dinas Perizinan Kota Yogyakarta. Dalam pengambilan data nama subyek penelitian tidak dicantumkan. Identitas subyek penelitian dirahasiakan.

\section{Hasil}

Di antara 375 pelajar putri yang memenuhi kriteria inklusi, 319 mengembalikan kuesioner (response rate $85 \%), 5$ dieksklusi karena data tidak lengkap. Enampuluh delapan koma lima persen subjek penelitian berasal dari kelas 7 , sebagian besar beragama Islam $(98,1 \%)$, karakteristik lain tertera pada Tabel 1 .

Hal-hal yang diperhatikan oleh remaja dalam pengambilan keputusan untuk menerima vaksinasi HPV adalah kehalalan vaksin $(58,6 \%)$, keamanan vaksin (45,9\%), tidak melanggar perintah agama yang dianut $(44,3 \%)$, dan diizinkan oleh orang tua (43\%) (Tabel 3).

Di antara 314 remaja putri tersebut belum ada yang mendapat vaksin HPV dan 9,9\% menyatakan bersedia untuk divaksinasi. Sebagian besar $(78,4 \%)$ remaja yang menolak vaksinasi menyebutkan ingin mendiskusikan dahulu dengan orang tua sebagai alasannya (Tabel 2).

\section{Pembahasan}

Remaja putri yang bersedia divaksinasi di Yogyakarta 9,9\%, lebih rendah dibanding remaja di Spanyol yang menerima vaksinasi HPV secara positif dengan penolakan keras $1 \%$, ragu-ragu 2,4\%, dan tidak memilih $21 \%$, atau remaja di Kanada dengan penolakan vaksinasi $49,3 \% .{ }^{10,11}$ Persentase kesediaan vaksinasi mahasiswa, wanita usia produktif, dan orang tua lebih tinggi. Penerimaan vaksinasi pada mahasiswa di Yogyakarta dan Hongkong $91,7 \%$ dan $69,9 \% .{ }^{12,13}$ Kesediaan vaksinasi pada wanita usia produktif di Tanzania 93\% dan pada perawat di Nigeria $90 \% .{ }^{1,14}$ Di Indonesia, $96,1 \%$ orang tua bersedia anaknya divaksinasi. ${ }^{15,16}$

Para remaja di Yogyakarta beralasan perlu berdis- 
Tabel 1. Karakteristik dasar subjek penelitian

\begin{tabular}{|c|c|c|}
\hline & n (314) & $\%$ \\
\hline \multicolumn{3}{|l|}{ Sekolah } \\
\hline SMP 2 Yogyakarta & 98 & 31,2 \\
\hline SMP 5 Yogyakarta & 116 & 31,8 \\
\hline SMP 8 Yogyakarta & 100 & 31,2 \\
\hline \multicolumn{3}{|l|}{ Kelas } \\
\hline 7 & 215 & 68,5 \\
\hline 8 & 62 & 19,7 \\
\hline 9 & 37 & 11,8 \\
\hline \multicolumn{3}{|l|}{ Agama } \\
\hline Islam & 308 & 98,1 \\
\hline Katolik dan Kristen & 6 & 2,0 \\
\hline Hindu dan Budha & 0 & 0,0 \\
\hline \multicolumn{3}{|l|}{ Pendidikan ayah } \\
\hline Dasar & 11 & 3,5 \\
\hline Tinggi & 303 & 96,5 \\
\hline \multicolumn{3}{|l|}{ Pendidikan ibu } \\
\hline Dasar & 12 & 3,8 \\
\hline Tinggi & 302 & 96,2 \\
\hline \multicolumn{3}{|l|}{ Pekerjaan ayah } \\
\hline Tidak tetap & 44 & 14,0 \\
\hline Tetap & 270 & 86,0 \\
\hline \multicolumn{3}{|l|}{ Pekerjaan ibu } \\
\hline Tidak bekerja & 119 & 37,9 \\
\hline Bekerja & 195 & 62,1 \\
\hline \multicolumn{3}{|c|}{ Jumlah anak dalam keluarga } \\
\hline$\leq 2$ & 183 & 58,3 \\
\hline$>2$ & 131 & 41,7 \\
\hline \multicolumn{3}{|l|}{ Asuransi kesehatan } \\
\hline Ada & 245 & 78,0 \\
\hline Tidak ada & 69 & 22,0 \\
\hline \multicolumn{3}{|c|}{ Jumlah pengeluaran keluarga setiap bulan } \\
\hline$>\operatorname{Rp} 1.200 .000,00$ & 266 & 84,7 \\
\hline$\leq \mathrm{Rp} 1.200 .000,00$ & 48 & 15,3 \\
\hline
\end{tabular}

Tabel 2. Alasan tidak bersedia vaksinasi

\begin{tabular}{lcc}
\hline Alasan & $\mathrm{n}(283)$ & $\%$ \\
\hline Saya ingin mendiskusikannya dulu dengan orang tua/wali & 222 & 78,4 \\
Saya ingin mendapat informasi lebih & 191 & 67,5 \\
Saya ingin mendiskusikannya dulu dengan petugas kesehatan & 94 & 33,2 \\
Saya takut disuntik & 65 & 23,0 \\
Saya pernah mendengar efek samping vaksin & 21 & 7,4 \\
Saya tidak percaya bahwa vaksin HPV itu bermanfaat & 0 & 0,0 \\
Saya tidak percaya dengan vaksinasi & 0 & 0,0 \\
\hline
\end{tabular}


Tabel 3. Hal-hal yang dipertimbangkan dalam pengambilan keputusan vaksinasi HPV

\begin{tabular}{lcc}
\hline & $\mathrm{n}(314)$ & $\%$ \\
\hline Kehalalan vaksin HPV & 184 & 58,6 \\
Keamanan vaksin HPV & 144 & 45,9 \\
Tidak melanggar perintah agama yang saya anut & 139 & 44,3 \\
Diizinkan oleh orang tua saya & 135 & 43,0 \\
Dianjurkan oleh Ikatan Dokter Anak Indonesia & 80 & 25,5 \\
Dapat melindungi dari infeksi HPV dan serviks & 77 & 24,5 \\
Gratis & 65 & 20,7 \\
Termasuk dalam program pemerintah & 58 & 18,5 \\
Dianjurkan oleh dokter saya & 32 & 10,2 \\
Informasi tentang vaksin HPV dapat dengan mudah didapat dari petugas kesehatan. & 19 & 6,1 \\
Orang lain juga mendapat vaksin yang sama & 4 & 1,3 \\
Digunakan di negara-negara lain & 3 & 1,0 \\
Vaksin dapat dengan mudah didapatkan di praktek dokter & 2 & 0,6 \\
\hline
\end{tabular}

kusi dengan orang tua/wali $(78,4 \%)$. Remaja umumnya beranggapan bahwa mereka adalah partisipan pasif dalam menentukan keputusan medis. ${ }^{10}$ Persetujuan orang tua adalah hal yang sangat penting. Hal ini sesuai budaya yang berlaku di Indonesia bahwa pemegang keputusan utama dalam tindakan anak adalah orang tua. Masa remaja adalah masa transisi dari anak ke dewasa, salah satu aspek kemampuan kognitif adalah dalam pengambilan keputusan, keputusan yang diambil pada fase awal usia remaja umumnya masih bergantung pada orang tua. Orang tua memiliki peran untuk mengarahkan remaja ke arah yang benar, mendampingi, dan mengontrol anak dalam setiap pengambilan keputusan. ${ }^{17}$

Alasan lain yang banyak disebutkan adalah ingin mendapat informasi lebih $(67,5 \%)$, ingin berdiskusi dengan tenaga kesehatan $(33,2 \%)$, takut disuntik (23\%), dan pernah mendengar efek samping vaksin $(7,4 \%)$. Serupa dengan penelitian kami, pada penelitian terhadap remaja di Australia yang tidak memperoleh vaksin HPV, alasan terbanyak disebutkan adalah kekhawatiran orang tua tentang keamanan vaksin, persepsi orang tua bahwa anaknya tidak berisiko, dan takut disuntik. ${ }^{18}$

Vaksin yang aman dan halal merupakan faktor utama pertimbangan remaja ketika menentukan kesediaan menerima vaksin HPV. Hal ini terkait bahwa 98,1\% remaja pada penelitian kami beragama Islam. Kemudian diikuti bahwa vaksinasi HPV tidak melanggar perintah agama yang dianut. Faktor tersebut muncul sebagai gambaran adanya masalah dengan persepsi masyarakat terhadap imunisasi saat ini. Kondisi tersebut tidak lepas dari gencarnya isu yang dilontarkan kelompok antivaksin di Indonesia yang menggunakan pendekatan ideologis berbasis Islam. Isu yang diusung biasanya menyangkut kehalalan dan keamanan vaksin. ${ }^{19}$

Merujuk pada Fatwa Majelis Ulama Indonesia (MUI) 2016 tentang imunisasi, imunisasi pada dasarnya dibolehkan (mubah) sebagai bentuk ikhtiar untuk mewujudkan kekebalan tubuh (imunitas) dan mencegah terjadinya suatu penyakit tertentu. Vaksin untuk imunisasi wajib menggunakan vaksin yang halal dan suci. Penggunaan vaksin imunisasi yang berbahan haram dan/atau najis hukumnya haram. Imunisasi dengan vaksin yang haram dan/atau najis tidak dibolehkan kecuali digunakan pada kondisi keterpaksaan yang mengancam jiwa manusia atau keterdesakan yang dapat menyebabkan pernyakit berat atau kecacatan pada seseorang. Belum ditemukan bahan vaksin yang halal dan suci, dan adanya keterangan tenaga medis yang kompeten dan dipercaya bahwa tidak ada vaksin yang halal. Dalam hal jika seseorang yang tidak diimunisasi akan menyebabkan kematian, penyakit berat, atau kecacatan permanen yang mengancam jiwa, berdasarkan pertimbangan ahli yang kompeten dan dipercaya maka imunisasi hukumnya wajib. ${ }^{20}$

Selama ini, pengetahuan tentang vaksin HPV banyak diperoleh remaja dari internet sebagai salah satu media elektronik yang mudah diakses. Media elektronik merupakan sumber informasi yang penting untuk 
menyosialisasikan vaksinasi HPV. Namun, informasi yang salah akan menyebabkan persepsi negatif sehingga kesediaan vaksinasi rendah. ${ }^{1}$ Penelitian di Spanyol dan Jerman menunjukkan situs laman tentang vaksin HPV sebagai sumber informasi yang sering diakses. Situs laman tersebut memberikan info kurang berimbang tentang kelengkapan, transparansi, dan dimensi infeksi HPV serta vaksinasi HPV. Cakupan media yang tidak berimbang ini berpotensi negatif terhadap program vaksinasi, apalagi jika informasi tersebut dibahas oleh para remaja tanpa interaksi dengan tenaga/sistem kesehatan. ${ }^{10}$

Remaja yang telah memiliki pengetahuan yang cukup tentang vaksinasi dan bersedia divaksinasi HPV (informed assent) tetap memerlukan persetujuan (informed consent) dari orang tua. Beberapa kepustakaan menunjukkan bahwa kebanyakan orang tua akan memberikan persetujuan vaksinasi apabila telah memahami risiko dan manfaat vaksinasi. ${ }^{15}$ Faktor lain yang dipertimbangkan adalah rekomendasi dari IDAI dan efektivitas vaksin HPV. Beberapa penelitian sebelumnya merangkum penolakan vaksinasi disebabkan oleh persepsi bahwa vaksin tidak diperlukan karena mereka tidak memiliki risiko, tidak memperoleh rekomendasi dari dokter atau tenaga medis lain untuk memberikan vaksinasi, khawatir akan keamanan dan efek samping vaksin, serta pengetahuan yang rendah tentang vaksin HPV. ${ }^{14,15,21,22}$

Jumlah kunjungan ke tenaga kesehatan terbukti meningkatkan kesediaan vaksinasi. ${ }^{11} \mathrm{Hal}$ ini menunjukkan bahwa meskipun sumber informasi utama adalah media massa, peran tenaga kesehatan dalam meningkatkan cakupan vaksinasi tetaplah penting. Informasi yang berkualitas dari sumber yang terpercaya sangat diperlukan agar remaja dan orang tua memperoleh informasi yang benar. Tenaga kesehatan yang proaktif dalam memberikan konseling tentang vaksinasi, terutama masalah keamanan vaksin dan efek samping yang mungkin timbul setelah pemberian vaksin kepada pasien dapat memperbaiki persepsi dan meningkatkan motivasi remaja untuk menerima dan melengkapi vaksinasi HPV. ${ }^{22,23}$

Gratis dan termasuk program pemerintah termasuk hal yang dipertimbangkan oleh remaja. Peran pemerintah melalui kebijakan agar vaksin dapat tersedia secara gratis dengan akses yang mudah untuk mengurangi hambatan masalah biaya dan ketersediaan vaksin HPV sangat diperlukan. ${ }^{1}$ Negara yang memberikan vaksinasi HPV secara gratis memiliki cakupan vaksinasi lebih tinggi. ${ }^{13}$ Program vaksinasi HPV berbasis sekolah melalui program BIAS mungkin solusi yang tepat untuk meningkatkan cakupan vaksinasi. Cakupan vaksinasi yang tinggi di negara yang telah memiliki program vaksinasi HPV nasional berbasis sekolah merupakan bukti kuat bahwa program ini bisa menjadi metode untuk meningkatkan cakupan vaksinasi HPV. ${ }^{11,23}$ Tentunya sebelum pemberian vaksin, sosialisasi dan edukasi kepada guru, orang tua, dan remaja sangat diperlukan untuk meningkatkan kesadaran dan kesediaan menerima vaksinasi HPV. Kelemahan penelitian kami adalah ketergantungan pada laporan responden sehingga berisiko terjadi bias informasi.

\section{Kesimpulan}

Kesediaan vaksinasi HPV pada remaja putri di Yogyakarta 9,9\%. Hal ini disebabkan karena remaja putri masih bergantung pada orang tua dalam pengambilan keputusan. Pemerintah dapat meningkatkan cakupan vaksinasi dengan program vaksinasi HPV nasional berbasis sekolah yang saat ini sedang dirintis. Pelaksanaan program ini tentunya disertai edukasi ke masyarakat. Edukasi dapat diberikan melalui tenaga kesehatan dan sosialisasi secara luas melalui media elektronik. Hal-hal khusus tentang kehalalan dan keamanan serta efek samping vaksin harus disampaikan dengan berimbang. Perlu dilakukan penelitian lanjutan yang mencakup kesediaan orang tua dalam pemberian vaksinasi pada remaja.

\section{Daftar pustaka}

1. Cunningham, Skrastins E, Fitzpatrick R. Cervical cancer screening and HPV vaccine acceptability among rural and urban women in Kilimanjaro Region, Tanzania. BMJ Open 2015;5:e005828.

2. Bruni L, Barrionuevo-Rosas L, Albero G. Human Papillomavirus and related diseases in Indonesia. Barcelona; 2016. Diakses tanggal 5 April 2017. Didapat dari: URL://http://www. hpvcentre.com.

3. Kementrian Kesehatan RI Pusat Data dan Informasi Kesehatan. Stop Kanker. Infodatin-Kanker. Kemkes; 2015.h.3.

4. Munoz N, Kjaer SK, Sigurdsson K. Impact of Human Papillomavirus (HPV)-6/11/16/18 vaccine on all HPVassociated genital diseases in young women. J Natl Cancer Inst 2010;102:325-39. 
5. Perlman S, Wamai RG, Bain PA, Welty T, Welty E, Ogembo JG. Knowledge and awareness of HPV vaccine and acceptability to vaccinate in sub-Saharan Africa: A systematic review. PLoS One. 2014;9: e90912. https://doi.org/10.1371/ journal.pone.0090912.

6. Fernández ME, Le YL, Fernández-espada N, Aragon AP, Colón-lópez V. Knowledge, attitudes, and beliefs about Human Papillomavirus (HPV) vaccination among Puerto Rican mothers and daughters, 2010 : a qualitative study. Prev Chronic Dis 2014;11:1-8.

7. Kemenkes Kesehatan Republik Indonesia. Peraturan Menteri Kesehatan Republik Indonesia Nomor 41 Tahun 2013 Tentang Penyelenggaraan Imunisasi. Kem Kes Republik Indonesia. Jakarta: 2013.h.1-100.

8. Biro Komunikasi dan Pelayanan Masyarakat. Cegah kanker serviks, siswi kelas lima di DKI Jakarta diimunisasi HPV 2016. Diakses tanggal 5 April 2017. Didapat dari: URL:http://www. depkes.go.idlarticle/print/16100600002/cegah-kanker-servikssiswi-kelas-lima-di-dki-jakarta-diimunisasi-hpv.html.

9. Pelucchi C, Esposito S, Galeone C. Knowledge of human papillomavirus infection and its prevention among adolescents and parents in the greater Milan area, Northern Italy. BMC Public Health 2010;10:378.

10. Fernández ME, Le YL, Fernández-espada N, Aragon AP, Colón-lópez V. Knowledge, attitudes, and beliefs about Human Papillomavirus (HPV) vaccination among Puerto Rican mothers and daughters, 2010 : a qualitative study. Prev Chronic Dis 2014;11:1-8.

11. Remes O, Smith LM, Alvarado-Llano BE, Colley L, Lévesque LE. Individual and regional level determinants of human papillomavirus (HPV) vaccine refusal: the Ontario Grade 8 HPV vaccine cohort study. BMC Public Health 2014;14:1047.

12. Farida M, Satibi. Hubungan pengetahuan dan persepsi mengenai Human Papilloma Virus (HPV) dan kanker serviks terhadap penerimaan vaksinasi HPV pada mahasiswi Universitas Gadjah Mada [skripsi]. Yogyakarta: Fakultas Farmasi Universitas Gadjah Mada, 2014.

13. Chiang V, Wong H, Yeung P. Attitude, acceptability and knowledge of HPV vaccination among local university students in Hong Kong. Int J Environ Res Public Health 2016;13:486.

14. Makwe CC, Anorlu RI. Knowledge of and attitude toward human papillomavirus infection and vaccines among female nurses at a tertiary hospital in Nigeria. Int J Womens Health 2011;3:313-7.

15. Blackman E, Thurman N, Halliday D. Multicenter study of human papillomavirus and the human papillomavirus vaccine: knowledge and attitudes among people of African descent. Infect Dis Obstet Gynecol 2013;2013:428582 doi: $10.1155 / 2013 / 428582$.

16. Jaspers L, Budiningsih S, Wolterbeek R, Henderson FC, Peters AAW. Parental acceptance of human papillomavirus (HPV) vaccination in Indonesia: A cross-sectional study. Vaccine 2011;29:7785-93.

17. Santrock J. Life-span development: Perkembangan masa hidup. Edisi Kelima. Jakarta: Erlangga; 2001.

18. Tung ILY, Machalek DA, Garland SM. Attitudes, knowledge and factors associated with Human Papillomavirus (HPV) vaccine uptake in adolescent girls and young women in Victoria, Australia. PLoS One. 2016;11:e0161846.

19. Yanuarso P. Menyoroti kontroversi seputar imunisasi. IDAI. Diakses tanggal 5 April 2017. Didapat dari:URL:http://www. idai.or.idlartikel/klinik/imunisasi/menyoroti-kontroversi-seputarimunisasi, 2015.

20. MUI KF. Fatwa Majelis Ulama Indonesia Nomor : 04 Tahun 2016 tentang Imunisasi. Jakarta: MUI KF; 2016.

21. Burdette AM, Gordon-Jokinen H, Hill TD. Social determinants of HPV vaccination delay rationales: Evidence from the 2011 National Immunization Survey-Teen. Prev Med Reports 2014;1:21-6.

22. Kester LM, Zimet GD, Fortenberry JD, Kahn JA, Shew ML. A national study of HPV vaccination of adolescent girls: Rates, predictors, and reasons for non-vaccination. Matern Child Health J 2013;17:879-85.

23. Kessels SJM, Marshall HS, Watson M, Braunack-Mayer AJ, Reuzel R, Tooher RL. Factors associated with HPV vaccine uptake in teenage girls: a systematic review. Vaccine 2012;30:3546-56. 